AKUNTANSI: Jurnal Akuntansi Integratif

Vol.6 No. 2 Tahun 2020

p-ISSN 2502-5376 e-ISSN 2715-0658

\title{
ZUHUD, SEBUAH LAKU TASAWUF UNTUK TAZKIYAH PERADABAN AKUNTANSI
}

\author{
Ali Farhan \\ STIE Mahardhika Surabaya \\ E-mail: ali.farhan@stiemahardhika.ac.id
}

\begin{abstract}
ABSTRAK
Penelitian ini bertujuan untuk merekonstruksi akuntansi modern dengan paradigma postmodernisme dan Zuhud sebagai pendekatan analisis dekosntruktif. Berdasarkan hasil analisis, praktik ilmu akuntansi haruslah kembali ke nilai-nilai ketuhanan; mengesakan Allah subhana wa ta'ala, menjalankan perintah dan menjauhi larangannya, juga menjadikan Allah subhana wa ta'ala sebagai tujuan hidup.
\end{abstract}

Kata Kunci: Zuhud, Postmodernisme, Akuntansi Syariah, Dekonstruksi Ilmu

\section{ABSTRACT}

This study aims to reconstruct modern accounting with the postmodernism paradigm and Zuhud as a decosntructive analysis approach. Based on the results of the analysis, the practice of accounting must return to the divine values; to force Allah subhana wa ta'ala, to carry out his commands and stay away from his prohibitions, also to make Allah subhana wa ta'ala as the goal of life.

Keyword: Zuhud, Postmodern, Shariah Accounting, Philosophy Deconstruction

\section{Pendahuluan}

Allah subhana wa ta'ala menciptakan semesta untuk ditundukkan kepada manusia, sebagaimana firmannya (QS. Al-Hajj: 65) dan QS. Al-Jatsiyah: 13.), denganNya manusiapun diciptakan untuk beribadah kepadaNya (Quran surat Ad Dzariayat; 56). Telah Allah subhana wa ta' ala cukupkan rezeki bagi semua makhluk ciptaanNya, namun demikian dalam kenyataan yang kita hadapi kesenjangan ekonomi masih terjadi. Riset yang dilakukan oleh Lakner et al (2019) menemukan 6,5\% penduduk dunia berada di bawah garis kemiskinan, sedangkan data dari Badan Pusat Statstik menyebutkan $17 \%$ masyarakat Indonesia masih berada dalam garis kemiskinan. Kebebasan yang diberikan Allah subhana wa ta'ala kepada manusia untuk mencari nafkah dan kekayaan telah membuat manusia alpa tentang tugasnya sebagai khalifah juga sekaligus pengahambaannya. Liberalisasi pemikiran dan perilaku pada akhirnya menjerat manusia pada kerangka berpikir baru; materialisme. Menjadikan manusia hanya mengejar kebahagiaan dunia sebagai pencapaian akhirnya, yang oleh Fitriyah (2016) dijelaskan sebagai pencapaian kebahagian hedonik.

Akuntansi telah menjadi bahasa bisnis yang memberikan informasi mengenai serangkian kegiatan ekonomi yang telah dilakukan, dengan informasi tersebut manusia memutuskan tentang berapa banyak harta harus dicari dan dikejar. Hal ini menunjukkan relasi antara alam ide dan material sebagaimana yang disebutkan oleh Plato dalam Prawironegoro 
(2016) tentang relasi alam ideal dan material, bahwa apa yang ada di dalam pikiran adalah apa yang akan diwujudkan pada aktifitas fisik, apa yang telah diyakini baik dalam alam pikiran adalah apa yang akan diwujudkan pada dunia materi (fisik), demikian pula sebaliknya bahwa dunia materi (fisik) merupakan pembentuk alam pikiran manusia. Artinya, bahwa dunia kita hari ini adalah bentukan dari alam pemikirian manusia-manusianya, jika kita temui ada kesenjangan ekonomi maka yang sebenarnya terjadi adalah ada penguasaan sumber daya ekonomi yang menumpuk pad pihak lain, begitu juga sebaliknya pikiran kita terbentuk dari apa yang kita temui sehari-hari, ketika penmpukan harta dianggap baik maka pikiran manusia akan terstimulus dengan itu, kedunaya adalah aktivitas yang saling mengikat dan mempengaruji. Informasi akuntansi sebagai sebuah bahasa (Prawironegoro, 2016) memberikan keyakinan kepada para pembacanya mengenai posisi keuangan yang karenanya maka membentuk alam pikiran manusia bahwa kenyataan materil adalah kenyataan akuntansi, sehingga mendorong manusia untuk menuju apa yang digambarkan oleh akuntansi.

Penumpukan kapital dan aset yang terwujud pada khazanah akuntansi turut mengambil tanggungjawab dalam terbentukanya pikiran-pikiran materialis-kapitalistik hari ini (Prawironegoro, 2016; Nugrahayati, 2016), yang karenanya manusia terstimulus untuk terus mengumpulkan asset bagi dirinya sendiri. Akuntansi sebagai sebuah bahasa dan keilmuan telah melegitimasi perilaku egois pada ekonomi kita yang kapitalistik hari ini (Truyuwono, 2000). Merasa memiliki harta dan mengejar dunia merupakan etos kerja yang secara tidak langsung terwujud dalam bahasa akuntansi, ketika tidak untung maka itu artinya buruk, mengapa? Karena capital atau modal tidak mendapatkan bagian kerjanya, hal ini bertentangan dengan pesan Rasulullah salallahu wa alaihi wassalam bahwa setiap perkara orang beriman adalah perkara yang baik baginya (HR Muslim nomor 2.999).

Zuhud sebagai sebuah laku tasawuf menyampaikan hal yang berbeda jauh dari pemikiran kapitalistik, Zuhud berarti menjadikan Allah subahna wa ta'ala sebagai tujuan hidup, sebagaimana sabda Rasulullah salallahu wa alaihi wassalam yang diriwayatkan oleh Imam Ahmad, yang artinya;

"Barangsiapa tujuan hidupnya adalah dunia, maka Allâh akan mencerai-beraikan urusannya, menjadikan kefakiran di kedua pelupuk matanya, dan ia tidak mendapatkan dunia kecuali menurut ketentuan yang telah ditetapkan baginya. Barangsiapa yang niat (tujuan) hidupnya adalah negeri akhirat, Allâh akan mengumpulkan urusannya, menjadikan kekayaan di hatinya, dan dunia akan mendatanginya dalam keadaan hina."

Dengan menjadikan Zuhud sebagai ontologi sekaligus epistemologi, artikel ini mencoba mendekosntruksi pemikiran kapitalistik di dalam akuntansi supaya dapat mencapai peradaban akuntansi yang lebih spiritual. Dekonstruksi aspek ontologis dan epistemologis pada akuntansi melalui zuhud ini dilakukan bertujuan untuk mewujudkan ilmu akuntansi memiliki fundamental tauhid yang kokoh, dengannya maka realitas kehidupan manusia akan menjadi lebih harmonis. Sebab humanisme dan materialisme pada ilmu pengetahuan modern telah menjadikan manusia menjadi terasingkan dan mengalami krisis multidimensi; ekologi, ekonomi, politik, dan moral (Salafudin, 2013). Berdasarkan latar belakang tersebutlah maka artikel ini disusun, melalui sebuah pertanyaan mendasar. Bagaimana mendekonstruksi nilainilai kapitalisme pada akuntansi dengan zuhud?

\section{Kajian Pustaka}

Teori Ontologi Al-Attas

Mengenai keterjadian (ontologi) Aristoteles pernah berkata bahwa segala sesuatu itu berasal dari dua entitas, yaitu materi dan bentuk. Pada diri manusia, materi adalah jasad dan bentuk adalah ruh, keduanya saling membutuhkan untuk tetap ada, namun baik ruh dan jasad 
keduanya berasal dari alam (Harun, 1973). Dengan demikian, maka pada setiap bentuk/ benda ada dua entitas yang saling mengisi keberadaaanya. Pemikiran dualitas-materi Aristoteles tentang wujud ini mendapat kritik dari Al-Attas, mengutip Damyati (2015) tentang Al-Attas bahwa mengetahui perkara yang haq diperlukan pengetahuan yang komprehensif tentang sebuah keterjadian, memahami secara korespondensif relasi antar realitas (peristiwa) dan halhal menegenai peristiwa itu sendiri. Hakikat adalah segala hal yang konstan dan mengetahuinya adalah perkara yang nyata, demikian pendapat Al-Attas (Damyati, 2015). Dualisme realitas dalam khazanah barat yang diwakili oleh pemikiran Aristoteles sebelumnya, merupakan wujud dari ketegangan pemikiran antara falsafah dan agama; antara pandangan alam inderawijasmani dan pandangan alam inderawi-khayal (Al-Attas, 2001). Dualitas pemikiran seperti ini yang kemudian melahirkan semangat pemikiran sekuler, yakni sebuah faham untuk melepaskan manusia dari ketergantungan kepada agama serta membebaskan manusia dari perjalanan sejarah.

Dualisme realitas yang melahirkan sekulerisme dan kemudian menekankan dunia sebagai satu-satunya tujuan hidup, bertentangan dengan pandangan Al-Attas. Bagi Al-Attas, ada adalah sebuah kebenaran yang komprehensif yang meliputi eksistensi paling rendah hingga eksistensi Yang Maha Tinggi. Ada menurut Al-Attas (1995) merupakan realitas yang aktif, dinamis dan memiliki kemungkinan yang tidak terbatas, sebagai akibat dari sifat wujud yang merupakan sifat Allah subhana wa ta'ala yang karenanya maka ada merupakan segala sesuatu yang terjadi karena ketetapanNya (sunnatullah). Maka dari itu maka setiap wujud atau ada harus bergerak dan terus hidup di bawah hukum Allah subhana wa ta'ala.

Zuhud

Zuhud secara bahasa artinya meninggalkan karena berdosa, Triana (2017) mendefininikan Zuhud sebagai keinginan untuk meninggalkan sesuatu karena mengharapkan yang lebih baik (Rida Allah). Hasan al Basri mengungkapkan Zuhud berarti menjadikan segala sesuatu baik ataupun buruk disebabkan semata karena Allah subhana wa ta'ala (Triana, 2017). Seperti Hasan al Basri, Ibnu Taimiyah dalam Majdi (1408 H) sebagaimana yang dikutip oleh Triana (2017) mengatakan Zuhud itu meninggalkan semua yang tidak bermanfaat untuk urusan akhirat dan meyakini bahwa segala hal yang baik ada di sisi Allah subhana wa ta'ala. Demikian pula Imam Ghazali mengungkapan pemahamannya mengenai Zuhud bahwa Zuhud itu berjalan di atas petunjuk Rasulullah salallahu alaihi wassalam dan para sahabat, mengambil bagian dari dunia ala kadarnya, menjaga syahwatnya tidak keluar dari syariat, dan senantiasa ingat tentang tujuan diciptakannya dunia ini (Majdi, 1408) sebagaimana yg dikutip oleh Triana (2017). Ibnu Katsir dalam tafsirnya pada Al-Quran surat Al-Qashas ayat 77, sebagaimana dikutip dari Triana (2017) berpendapat;

"Pergunakanlah segala pemberian Allah subhana wa ta'ala. berupa harta yang banyak, kenikmatan yang langgeng, untuk taat kepada Rabbmu dan mendekatkan diri kepada kepada Allah SWT. dengan berbagai bentuk pendekatan yang akan menghasilkan balasan di Dunia dan Akhirat."

Lebih lanjut dalam tafsir Ibnu Katsir (Triana, 2017) sifat Zuhud semestinya tidak membuat seorang individu meninggalkan dunianya, Allah subhana wa ta'ala berpesan agar seseorang tidak lupa dengan haknya, dan adalah keniscayaan jika setiap hak itu wajib untuk ditunaikan haknya, demikian arti dari kata nashībaka min al-duny $\bar{a}$, makan, menikah, tempat tinggal, istri, tetangga, yang tidak boleh dillupakan haknya bagi seseorang.

Dengan demikian maka dapat dipahami bahwa Zuhud berarti mengingat Allah subhana wa ta'ala sebagai pencipta yang menjadikan alam semesta ini ada dan menjadi akhir dari perjalaan hidup manusia, Zuhud berarti menjadikan Allah subhana wa ta'ala sebagai argument paling mendasar sekaligus tujuan untuk hidup sebagai manusia. 


\section{Metode Penelitian}

Artikel ini merupakan artikel yang berbasis studi pustaka yaitu penelitian yang mengambil data dan mengolah data kepustakaan. Adapun pendekatan yang digunakan dalam melakukan analisis adalah postmodernisme, dengan analisis sinergi oposisi biner.

\section{Postmodernisme}

Modernisme yang menjanjikan kemajuan dan kemapanan ternyata berakhir pada penindasan dan disorientasi hidup (Setiawan dan Sudrajat, 2018). Demikian pula kebenaran pengetahuan dalam pandangan modernisme harus bebas nilai, terbebas dari subjektifitas dan keyakinan manusia (Setiawan dan Sudrajat, 2018). Berawal dari kejumudan peradaban yang anti-klimaks seperti itu semangat postmodern lahir. Postmodernisme adalah sebuah paradigma dalam pengetahuan memberikan kritikan-kritikan terhadap modernisme yang dianggap telah gagal dan bertanggung jawab terhadap kehancuran martabat manusia. Postmodern berargumen bahwa ilmu modern yang dominatif dan eksploitatif harus ditolak dan digantikan dengan ilmu yang 'mengalir' mengikuti aliran waktu (Prawironegoro, 2016).

Sebagai sebuah paradigma yang inklusif postmodernisme tidak mengenal pola pikir oposisi biner (dualitas) seperti halnya modernisme (misalnya, bentuk/ substansi, salah/ benar, egoistik/altruistik dan lain-lain) (Triyuwono, 2009). Mengutamakan salah satu dan meninggalkan yang lainnya menjadikan manusia tidak memenuhi hak-haknya dengan benar, padahal setiap hak itu wajib ditunaikan. Pola pikir modern yang dikotomis tidak sejalan dengan paradigma postmodern dan konsep Zuhud, di mana dalam mengejar dunia Allah subhana wa ta 'ala tidak boleh ditinggalkan, dan dalam mengejar ridha Allah subhana wa ta'ala bagian atas dunia juga tidak boleh ditinggalkan, yaitu kesejahteraan ekonomi, kesenangan terhadap perkara-perkara yang diperbolehkan oleh agama. Demikian pula konsep ontologi Al-Attas yang menjadikan Allah subhana wa ta'ala sebagai argument untuk ada dan tujuan untuk tetap menjadi $a d a$, maka dikotomi antara 'dunia' dan 'ruh' menjadi sesuatu yang harus ditolak, dikotomi 'untung' dan 'rugi' juga harus ditunda, sebab tidak sejalan dengan nafas Zuhud dan wujud. Berdasarkan argument tersebut maka, analisis penelitian dalam paradigma postmodern ini menggunakan sinergi oposisi biner, yaitu 'mengawinkan' dua hal yang saling bertentangan (oposisi biner) ke dalam satu kesatuan (Triyuwono, 2009).

Paradigma postmodern menjadi cara pandang mengenai sebuah persoalan dalam riset ini, yaitu cara pandang yang inklusif. Tidak dikotomis. Bahwa dalam perkara-perkara hidup yang praktis khazanah pengetahuan yang transenden tidak boleh dilepaskan, oleh karenanya dalam memandang realitas akuntansi maka cara pandang dikotomis atas akuntansi juga harus ditanggalkan; akuntansi tidak hanya berperan untuk pertanggungjawaban kepada shareholder tapi juga kepada Allah subhana wa ta'ala. Melalui paradigma ini maka diwujudkan suatu metodologi dekonstruksi akuntansi, yaitu sinergi oposisi biner, 'mengawinkan' dua hal yang saling bertentangan (oposisi biner) ke dalam satu kesatuan (Triyuwono, 2009) dengan menggunakan data-data yang berupa kepustakaan. Kerangka berpikir ini diilustrasikan ke dalam Gambar. 1. 


\section{Gambar 1 \\ Kerangka Berpikir Penelitian}

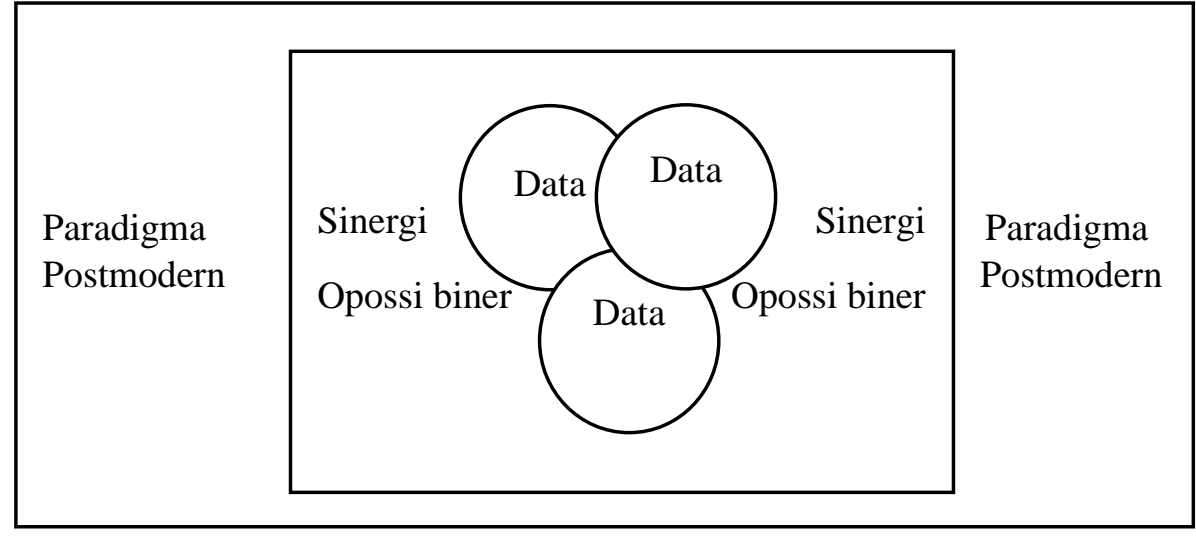

Adapun konsep-konsep akuntansi yang akan dilakukan proses dekonstruksi adalah sebagai berikut; 1) kerangka kerja konseptual lapis satu; tujuan pelaporan keuangan yang berorientasi pada stakeholder dan shareholder, 2) bottom line laporan keuangan yang bermuara pada Laba/ rugi, 3) Asumsi Moneter unit ,4 ) Asumsi Going Concern Perusahaan. Keempat kerangka kerja konseptual ini diangkat dalam artikel, sebab secara konseptual keempat poin tersebut bertentangan dengan konsep zuhu; bahwa pertanggungjawaban tertinggi adalah kepada Allah subhana wa ta'ala, kesadaran untuk menerima semua kondisi karena Allah. Bukan selalu mengejar laba. Luasnya nikmat Allah subhana wa ta'ala yang tidak dapat dibatasi dalam unit moneter, serta kembalinya setiap jiwa kepada Allah subhana wa ta'ala, merupakan konsep dalam zuhud yang tidak sejalan dengan kerangka kerja koneptual laporan keuangan yang.

\section{Pembahasan}

Berikutnya, sebagai kerangka berpikir baru akuntansi pandangan ontologis dan epistemologis ilmu akuntansi akan didekonstruksi, melalui paradigma postmodern dengan pendekatan sinergi oposisi biner Zuhud sebagai sebuah laku tasawuf akan menjadi pondasi sekaligus tiang-tiang keilmuan praktik akuntansi.

Sebagaimana akuntansi yang muncul sebagai sebuah praktik (Brown, 1905), Zuhud pun lahir sebagai sebuah praktik tasawuf (Syamhudi, 2017). Keduanya tumbuh bersamaan dengan peradaban dan kemanusiaan itu sendiri. Akuntansi pada awal kemunculannya selalu diasosiasikan pada nilai-nilai etika dan ketuhanan seiring waktu dalam perkembangannya makin terjebak pada modernitas materialis-kapitalis, yang kemudian melegitimasi perilakuperilaku nir-etis yang predatoris sebagai perwujudan dari lingkungan pembentuknya. Oleh karenanya Zuhud hadir dalam kekeringan nilai praktik ilmu akuntansi.

Sinergi oposisi biner sebagaimana disebutkan dalam Triyuwono (2009) merupakan sebuah pendekatan yang meninternalisasikan nilai-nilai yang termarjinalkan dari praktik akuntansi salama satu abad terakhir. Adapun yang akan didekonstruksi dalam praktik akuntansi adalah sebagai berikut; 1) kerangka kerja konseptual lapis satu; tujuan pelaporan keuangan yang berorientasi pada stakeholder dan shareholder, 2) bottom line laporan keuangan yang bermuara pada Laba/ rugi, 3) Asumsi Moneter unit ,4) Asumsi Going Concern Perusahaan.

Zuhud berarti menjadikan Allah subhana wa ta' ala sebagai tujuan untuk menerima dan menolak segala sesuatu, dengan Zuhud berarti seorang individu telah menjadikan Allah subhana wa ta' ala sebagai prioritasnya, hal ini bertentangan dengan tujuan pelaporan keuangan yang menjadikan shareholder sebagi puncak kewajiban pelaporan keuangan. Hal ini kemudian akan berdampak pada upaya manajemen untuk mencari laba, juga bagaimana manajemen mengelola keberlangsungan usahanya. Adapun nilai-nilai Zuhud dan praktik ilmu akuntansi modern akan disajikan ke dalam table 1: 
Tabel 1

Sinergi Oposisi Biner

\begin{tabular}{|l|l|}
\hline \multicolumn{1}{|c|}{ Zuhud } & \multicolumn{1}{c|}{ Akuntansi Modern } \\
\hline Pertanggungjawaban kepada Allah & $\begin{array}{l}\text { Pertanggungjawaban kepada utama } \\
\text { kepada shareholder }\end{array}$ \\
\hline Menerima semua kondisi karena Allah & Hanya berorientasi pada Laba \\
\hline $\begin{array}{l}\text { Rahmat Allah demikian luas tidak dapat } \\
\text { dihitung }\end{array}$ & $\begin{array}{l}\text { Moneter Unit, artinya segala sesuatunya } \\
\text { harus diakui dalam satuan uang }\end{array}$ \\
\hline $\begin{array}{l}\text { Sewaktu-waktu kita akan kembali pada } \\
\text { Allah }\end{array}$ & $\begin{array}{l}\text { Asumsi Going concern, artinya } \\
\text { Perusahaan diasumsikan akan hidup } \\
\text { selamanya }\end{array}$ \\
\hline
\end{tabular}

1. Merekonstruksi Kembali Tujuan Pelaporan Keuangan.

Bagi praktik ilmu akuntansi modern, informasi yang dilahirkan dari laporan keuangan adalah ditujukan untuk pemodal dan para pemangku kepentingan perusahaan. Hal ini disebabkan pihak yang paling berhak mendapatkan informasi tersebut adalah para pemodal, yaitu pihak yang telah mengorbankan sumber daya ekonominya untuk perusahaan. Hal ini menghilangkan hal yang paling mendasar bagi setiap eksistensi, yaitu keberadaan Allah subhana wa ta' ala. Seluruh harta kekayaan kita, pendengaran, penglihatan, anak dan istri sesungguhnya adalah titipan dari Allah subhana wa ta'ala yang akan dimintai pertanggung jawaban di akhirat nanti, sebagaimana firman Allah subhana wa ta'ala dalam Al-Quran, sebagai berikut yang artinya;

"Bagi orang-orang yang memenuhi seruan Tuhannya, (disediakan) pembalasan yang baik. Dan orang-orang yang tidak memenuhi seruan Tuhan, sekiranya mereka mempunyai semua (kekayaan) yang ada di bumi dan (ditambah) sebanyak isi bumi itu lagi besertanya, niscaya mereka akan menebus dirinya dengan kekayaan itu. Orang-orang itu disediakan baginya hisab yang buruk dan tempat kediaman mereka ialah Jahanam dan itulah seburuk-buruk tempat kediaman." (QS. Ar-Ra'du:18)

"Apakah manusia mengira, bahwa ia akan dibiarkan begitu saja (tanpa pertanggung jawaban)?”(QS. Qiyamah: 36)

"Sesungguhnya pendengaran, penglihatan dan hati, semuanya itu akan diminta pertanggungjawabannya." (QS. Al Isra': 36)

Dengan menjadikan Allah subhana wa ta'ala sebagai prioritas maka apa yang dilakukan oleh manajemen akan mempertimbangkan keridhaan Allah subhana wa ta'ala; halal/ haramnya zat yang dipakai, zalim/ adilnya dalam membina bisnis dengan rekanan. Karena orang yang Zuhud adalah orang yang senantiasa menjadikan kebaikan akhirat sebagai prioritas. Dengan menjadi Zuhud maka segala aspek operasional manajemen akan berorientasi akhirat dan menghilangakn sifat tamak, sebagaimana firman Allah subhana wa ta'ala dalam Al-Quran Surat Al-Maidah ayat 87 , yang artinya;

"Hai orang-orang yang beriman, janganlah kamu haramkan apa-apa yang baik yang telah Allah halalkan bagi kamu, dan janganlah kamu melampaui batas. Sesungguhnya Allah tidak menyukai orang-orang yang melampaui batas." 
Dengan menjadikan Allah subhana wa ta'ala sebagai pijakan ontologis eksistensial praktik ilmu akuntansi, maka sebagai sebuah bahasa akuntansi akan senantiasa menciptakan dunia idea yang berwawasan akhirat yang dengannya diharapkan akan dapat menciptakan lingkungan praktik yang serupa. Konsep ini sejalan dengan wacana akuntansi syariah Triyuwono (2009) syariah entrerprise theory, bahwa penanggungjawab amanah dari Allah subhana wa ta'ala adalah manusia dan pertanggungjawaban tertinggi adalah kepada Allah subhana wa ta'ala, karenanya maka sebuah entitas harus berjalan sesuai dengan hukum-hukum Allah subhana wa ta'ala

\section{Profit Oriented}

Disebabkan laporan keuangan akuntansi ditujukan untuk pengukuran kinerja dan pertanggungjawaban manajemen kepada principal, maka tolok ukur kinerja dilandaskan pada seberapa mampu manajemen meningkatkan kemakmuran principal melalui laba, oleh sebab itu bisnis dalam khazanah akuntansi senanstiasa berorientasi pada penimbunan saldo laba. Praktik profit oriented ini tidak selaras ketika ontologi praktik keilmuan akuntansi telah melandaskan dirinya pada tauhid. Mengesakan Allah subhana wa ta'ala.

Sebagai perwujudan dari hati yang Zuhud maka sesungguhnya orientasinya adalah Allah subhana wa ta'ala. Jika yang diniatkan adalah Allah subhana wa ta'ala, maka yang dituju adalah Allah subhana wa ta'ala, sebagaimana firman Allah subhana wa ta'ala, yang artinya;

“Allah Ta'ala berfirman: Aku sesuai persangkaan hamba-Ku. Aku bersamanya ketika ia mengingat-Ku. Jika ia mengingat-Ku saat bersendirian, Aku akan mengingatnya dalam diri-Ku. Jika ia mengingat-Ku di suatu kumpulan, Aku akan mengingatnya di kumpulan yang lebih baik daripada pada itu (kumpulan malaikat)." (HR. Bukhari, no. 6970 dan Muslim, no. 2675)

"Barangsiapa tujuan hidupnya adalah dunia, maka Allâh akan mencerai-beraikan urusannya, menjadikan kefakiran di kedua pelupuk matanya, dan ia tidak mendapatkan dunia kecuali menurut ketentuan yang telah ditetapkan baginya. Barangsiapa yang niat (tujuan) hidupnya adalah negeri akhirat, Allâh akan mengumpulkan urusannya, menjadikan kekayaan di hatinya, dan dunia akan mendatanginya dalam keadaan hina." (Hadits Riwayat Imam Ahmad, V/183; Ibnu Majah, 4105)

Menjadikan laba sebagai tujuan hidup perusahaan merupakan hal yang fatal, bukan hanya secara ontologis tauhid, namun juga filosofis praktik. Riduwan et al (2010) mengungkapkan bahwa laba akuntansi merupakan sesuatu yang abstrak, 'benar' dalam tingkatan konseptual akuntansi namun secara faktual objektifikasi akuntansi ternyata juga penuh dengan problema ketika berbicara menyoal asas akrual yang harus dihadapkan ada kejadian-kejadian faktual yang nyatanya tidak dapat ditangkap dalam konsep akrual itu sendiri sebagai basis utama pencatatan akuntansi, hal inilah yang menjadikan laba akuntansi sebagai realitas yang nirmakna. Kecuali, tentu dalam logosentrisme akuntansi saja. Maka benarlah firman Allah subhana wa ta'ala "“'Barangsiapa tujuan hidupnya adalah dunia, maka Allâh akan mencerai-beraikan urusannya, menjadikan kefakiran di kedua pelupuk matanya.." jika dunia (laba) yang menjadi ukuran maka Allah akan menceraiberaikan urusannya, pada saat yang sama Riduwan et al ( 2010 ) mengungkap bahwa laba akuntansi merupakan sebuah hal yang abstrak, yang mana sebenarnya ketika laba menjadi tujuan, sebenarnya manusia telah terjebak untuk mengejar sesuatu yang tidak ada .

Laba (begitu juga rugi) merupakan bagian dari perjalanan, dengan bersikap Zuhud maka manusia tidak akan terbuai dengan kondisinya, Allah subhana wa ta' ala berfirman dalam Al Quran surat Al-Hadid ayat, 23 yang artinya; 
"(Kami jelaskan yang demikian itu) supaya kamu jangan berduka cita terhadap apa yang luput dari kamu, dan supaya kamu jangan terlalu gembira terhadap apa yang diberikan-Nya kepadamu. Dan Allah tidak menyukai setiap orang yang sombong lagi membanggakan diri."

"Sungguh menakjubkan keadaan seorang mukmin. Seluruhnya urusannya itu baik. Ini tidaklah didapati kecuali pada seorang mukmin. Jika mendapatkan kesenangan, maka ia bersyukur. Itu baik baginya. Jika mendapatkan kesusahan, maka ia bersabar. Itu pun baik baginya." (HR. Muslim, no. 2999)

Tidaklah untung/ rugi itu merupakan baik atau buruk melainkan hanya ujian bagi seorang manusia, yang karenanyalah maka kita akan beroleh kebaikan. Inna qolaktujinna wal intsa illa liya'budun, tidaklah Allah ciptakan jin dan manusia kecuali hanya untuk beribadah kepadaNya. Beribadah artinya menjauhi yang dilarang dan melaksanakan apa yang diperintahkan, larangan-larangan Allah subhana wa ta'ala diantaranya; 1) dilarang berjudi (QS: Al-Maidah; 90 ), 2) dilarang memungut dan memberikan riba (Quran Surat Al-Baqarah: 275), 3) dilarang melakukan transaksi dengan barang haram (Hadits Riwayat Bukhari no. 2236 dan Hadits Riwayat Muslim, no. 4132) dan dilarang berbuat zalim (Quran Surat Saba: 40). Adapun yang Allah subhana wa ta'ala perintahkan diantaranya; 1) bermanfaat bagi sebanyakbanyaknya makhluk (Hadits Riwayat Ahmad, 2) Menunaikan zakat, 3) berlaku adil (Quran Surat Almaidah: 8).

Dengan demikian maka bottom line laporan keuangan yang tadinya bermuara pada saldo laba dapat digeser menjadi saldo zakat/ waqaf sebagai perwujudan melaksanakan perintah Allah subhana wa ta'ala untuk menjadi manfaat bagi alam. Contoh konkret dari tiadanya saldo laba adalah laporan keuangan pada organsasi nirlaba, sebab setiap surplus dana akan terus bergulir menjadi aset organisasi yang tujuannya adalah untuk melayani masyarakat. Dengan demikian maka tujuan perusahaan kemudian bergeser menjadi memakmurkan stakeholder dalam ketaatan kepada Allah subhana wa ta'ala, bukan lagi penimbunan laba.

3. Asumsi Unit Moneter

Laporan keuangan sebagaimana dimandatkan di dalam kerangka konseptual pelaporan keuangan, harus dinyatakan (diinformasikan) dalam satuan moneter. Bahwa setiap transaksi atau aktivitas Perusahaan dalam kurun waktu tahun buku harus berada dalam satuan keuangan. Tujuanya supaya laporan keuangan dapat dibandingkan, namun kembali menurut Riduwan et al ( 2010 ) konsep-konsep akuntansi secara akademis terkadang tidak sanggup menangkap kejadian-kejadian yang nyata, demikain pula Triyuwono (2009) yang beranggapan bahwa akuntansi hanya menangkap realitas materi saja, padahal realitas bukan hanya aspek materil namun juga yang imateril. Pembatasan praktik akuntansi yang hanya berfokus pada kuantitas sudah membuatnya menjadi tidak lagi objektif, sebab objektifitas transaksi adalah keterlibatan faktor kualitatif juga kuantitatif. Sejalan dengan Riduwan et al (2010) pada akhirnya konsep akuntansi dalam level akademis tidak dapat menggambarkan kejadian secara utuh yang terjadi pada kejadian yang sesungguhnya.

Asumsi unit moneter tidak dapat merekam kejadan-kejadian yang sifatnya normatif, kualitiatif dan spiritual yang melingkupi sebuah lingkungan bisnis. Asumsi moneter juga menggiring pembacanya hanya untuk memahami realitas fisik semata dari sebuah aktivitas Perusahaan, sedangkan nilai-nilai yang lain teralenansi (terpinggirkan) (Triyuwono, 2009). Sedangkan dalam Zuhud, materialitas harus dilepaskan. Zuhud mengharuskan untuk fokus pada spiritualitas. Oleh sebabnya, akuntansi juga harus memberikan ruang untuk spiritualitas hadir. Hal ini dapat dilakukan dengan menyediakan catatan atas laporan keuangan yang menjelaskan peristiwa-peristiwa imateril yang terjadi dalam lingkungan manajemen, seperti bagaimana nilai-nilai perusahaan diselaraskan dengan syariah (hukum-hukum Allah subhana wa ta'ala), bagaimana manajemen konflik dan risiko diterapkan dengan mengedepankan 
humanisme dan spiritualitas, bagaimana perusahaan merumuskan kebijakan strategisnya sehingga tidak meenzalimi rekanan dan banyak hal lain yang bisa dirumuskan berkenaan dengan ini.

\section{Asumsi Going Concern}

Qullunafsin dzaiqotul maut, sesungguhnya setiap yang bernyawa pasti akan mati (QS. Al Imran: 185). Demikian firman Allah subhana wa ta' ala di dalam Al-Quran. Allah subhana wa ta' ala menjamin kecukupan rezeki bagi setiap makhluknya (QS QS. Al Imran: 185), kesenjangan muncul, kezaliman hadir adalah disebabkan ketika ada sekolompok kecil orang yang menghimpun suber daya ekonomi lebih banyak daripada yang lain. Kapitalisme lahir dari etos seperti itu, dari keinginan untuk hidup selamanya. Zuhud adalah pendeknya angan-angan (Triana, 2017), asumsi Going Concern dengan sendirinya batal ketika epistemologi akuntansi telah disusun di atas prinsip Zuhud. Allah subhana wa ta' ala tidak melarang untuk mencari dunia, sebagaimana firmanNya dalam surat Al Qashas ayat 77, yang artinya;

"Dan carilah pada apa yang telah dianugerahkan Allah kepadamu (kebahagiaan) negeri akhirat, dan janganlah kamu melupakan bahagianmu dari (kenikmatan) duniawi dan berbuat baiklah (kepada orang lain) sebagaimana Allah telah berbuat baik, kepadamu, dan janganlah kamu berbuat kerusakan di (muka) bumi. Sesungguhnya Allah tidak menyukai orang-orang yang berbuat kerusakan."

Namun berlama-lama mengejar dunia dengan berangan-angan bahwa sebuah bisnis harus hidup selamanya merupakan bentuk keingkaran terhadap sunnatullah, seseorang yang Zuhud adalah orang yang dapat menerima baik atau buruknya kondisinya semata untuk mencari ridha Allah (Majdi, $1408 \mathrm{H}$ ).

Asumsi going concern memberikan konsekuensi pencatatan berdasar biaya historis yang fungsinya adalah untuk mengevaluasi perubahan asset dari satu masa ke masa yang lain dan mengestimasi usia ekonomisnya. Dalam kerangka berpikir Zuhud seseorang harus mawas diri tentang kondisinya hari ini, tidak boleh risau tentang bertambah atau berkurangnya asetnya. Oleh sebab itu sebagai akibat dinihilkannya going concern maka demikian pula biaya historis sebagai metode perhitungan.

Kemampuan perusahaan untuk membayar kewajiban-kewajibannya menjadi lebih relevan digunakan untuk mengukur kinerja Perusahaan dibandingkan dengan biaya historis yang masih dihantui konsep akrual yang nisbi juga lebih sejalan dengan konsep Zuhud, sebab apabila hari ini perusahaan dinyatakan pailit, maka akuntansi telah menyediakan informasi yang memadai untuk menutupi kewajiban-kewajiban perusahaan. Current cash equivalent yang ditawarkan oleh Chambers (1970) dalam (Deegan, 2004) dapat menjadi sebuah alternatif metode pengukuran sebagai pengganti biaya historis yang sudah tidak lagi relevan dengan Zuhud.

\section{Kesimpulan}

Zuhud sebagai ontologis sekaligus epistemologis praktik ilmu akuntansi telah menyediakan kerangka kerja konseptual yang mapan untuk menjawab kebutuhan dalam praktik ilmu akuntansi. Dengan Zuhud maka akuntansi modern akan mengalami tazkiyah (penyucian) dari nilai-nilai modernisnme yang materialistik. Zuhud akan mengembalikan akuntansi sebagaimana awal kemunculannya; representasi ketaatan kepada Tuhan melalui integritas pencatatan (Brown, 1905), dengan Zuhud maka realitas bisnis akan di dorong untuk lebih spiritual; menghindarkan diri dari yang haram, tidak zalim, tidak serakah, berorientasi kepada kebutuhan umat dan ketaatan kepada Allah subhana wa ta'ala dan tetap berada dalam koridor bisnsi yang professional. 
Aplikasi nilai Zuhud dalam praktik ilmu akuntansi akan menciptakan kerangka konseptual dengan tujuan pelaporan keuangan yang berdasarkan tauhid, yang kemudian akan melahirkan operasional bisnis yang berlandaskan pada etika dan hukum-hukum Allah subhana wa ta'ala; melahirkan konservatisme yang berorientasi ketuhanan, yakni kehati-hatian yang beranggung jawab dalam perkara akhirat, seperti pengakuan hak dan kewajiban kontinjensi yang pada akhirnya mengusulkan current cash equivalent sebagai metode pencatatan; menawarkan pelaporan aspek kualitatif pada laporan keuangan, seperti proses bisnis, manajemen konflik, dan tingkat stress; manawarkan untuk menjadikan zakat/waqaf/peningkatan asset produktif untuk stakeholder dan masyarakat sebagai tolok ukur kinerja Perusahaan.

\section{Daftar Pustaka}

Al-Quran

Al-Atas, Syed Muhammad Naquib. 2001. Risalah untuk kaum Muslimin. ISTAC.

Al-Atas, Syed Muhammad Naquib. 1995. Prolegomena to The Metaphysics of Islam An Exposition of the Fundamental Element of the Worldview of Islam. Kuala Lumpur, ISTAC.

Brown, Richard. J S Mackay. Edward, Boyd. J Row, Fogo; Alexander Sloan. 1905. A history of accounting and accountants. Edinburgh, T.C. \& E.C.

Deegan, C. 2014. Financial accounting theory (edisi ke-4). Australia: McGraw-Hill Education Pty Ltd.

Damyati, Akhmad Rofii. 2015. Syed Muhammad Naquib Al-Attas dan Konsep Metafisik dalam Islam. El Furqonia Volume: 01. No. 1.

Fitriyah, Lailatul. 2016. Jangan Terlalu Materialistik! Materialisme Sebagai Tolak Ukur Hadits Kepuasan Hidup. Psikovidya, 20(1), 1-8.

Lakner, Christoph. Mahler, Daniel Gerszon. Nagre, Mario. 2019. How Much Does Reducing Inequality Matter for Global Poverty? .Policy Research Working Paper: 8869. World Bank.

Nasution, H. 1973. Falsafat dan misticisme dalam Islam. Bulan Bintang.

Prawironegoro, Darsono. Triyuwono, Iwan. Mulawarman, Aji Dedi. 2016. Filsafat Ilmu Akuntansi: Berpikir Kontemplatif, Holistik, Intuitif, Imajinatif, Kreatif, Rasional dan Radikal dalam Akuntansi. Jakarta:.Mitra Wacana Media.

Riduwan, Akhmad. Triyuwono, Iwan. Irianto, Gugus. Unti, Ludigdo. Semiotika Laba Akuntansi: Studi Kritikal-Postmodern Derridean. Jurnal Akuntansi dan Keuangan Indonesia, Volume 7. No. 1.

Salafudin. 2013. Islamisasi Ilmu Pengetahuan. Forum Tabiyah, Volume 11. No. 2.

Setiawan, Johan. Sudrajat, Ajat. 2018. Pemikiran Postmdernisme Pandangannya Terhadap Ilmu Pengetahuan. Jurnal Filsafat, ISSN: 0853-1870 (p); 2528-681. Vol. 28, No. 1 (2018), p. 25-46, doi: 10.22146/jf.33296.

Syamhudi, M. Hasyim. 2017. Akhlak-Tasawuf. Madani Media.

Triana, Rumba. 2017. Zuhud Dalam Alquran. Al Tadabbur: Jurnal Ilmu Al-Quran dan Tafsir. Volume 2, nomor 3.

Triyuwono, Iwan. 2009. Perspektif, Metodologi, dan Teori Akuntansi Syariah. Raja Grafindo Persada.

Triyuwono, Iwan. (2000). Akuntansi Syari'ah: Paradigma Baru dalam Wacana Akun tansi. Materi Seminar Nasional Ekonomi Islam Fakultas Ekonomi Universitas Diponegoro 11-13 Mei 2000. 